\title{
Partisipasi Semu Ibu Hamil di Posyandu
}

\section{Pseudo Participation of the Pregnant Women in Integrated Services Post}

\author{
Shrimarti Rukmini Devy* Muhammad Hakimi** Yayi Suryo Prabandari** Totok Mardikanto*** \\ Dhody Rafsandjani* Sofyan Haryanto*
}

\author{
*Fakultas Kesehatan Masyarakat Universitas Airlangga Surabaya, **Fakultas Kedokteran Universitas Gadjah \\ Mada Yogyakarta, **Fakultas Pertanian Universitas Negeri Sebelas Maret Solo
}

\begin{abstract}
Abstrak
Salah satu kebijakan pembangunan bidang kesehatan yang dipergunakan untuk mengatasi kesehatan ibu hamil adalah pemberdayaan masyarakat. Keberhasilan pemberdayaan dapat diketahui melalui berbagai cara, salah satunya partisipasi masyarakat. Penelitian ini bertujuan untuk mengidentifikasi kondisi sosial, budaya, dan ekonomi yang mempengaruhi partisipasi ibu hamil ke posyandu. Penelitian ini menggunakan rancangan etnografi. Teknik yang digunakan untuk pengumpulan data adalah wawancara mendalam, focus group discussion, observasi dan nominal group process. Data yang diperoleh dari pendekatan kualitatif akan diolah dengan content analysis. Hasil penelitian ini menunjukkan kondisi sosial, budaya dan ekonomi yang mempengaruhi partisipasi ibu hamil ke posyandu di Desa Rapa Laok, bermula pada faktor kemiskinan. Kondisi sosial dan budaya yang berpengaruh pada partisipasi ibu hamil, yaitu kepercayaan pada mitos dan pantangan makanan bertentangan dengan aturan medis. Kondisi ekonomi yang berpengaruh pada partisipasi ibu hamil, yaitu beban fisik dan psikis ibu hamil terhadap kesejahteraan keluarga berlebihan. Ibu hamil datang untuk memeriksakan diri ke posyandu bukan karena kesadaran untuk menjaga kesehatan tetapi untuk mendapat imbalan satu dus mi instan. Model partisipasi ibu hamil ke posyandu yang tepat adalah dengan pendekatan nondirektif (partisipatif) yang produktif.
\end{abstract}

Kata kunci: Ibu hamil, partisipasi, posyandu

\footnotetext{
Abstract

One of the development policies in health sector that is currently used to overcome maternal health issues is the community empowerment. The success of the community empowerment can be measured through the people participation. The objectives is to identify the social, cultural, and economic conditions which might influence the pregnant women participation in integrated service post. This study used a qualitative approach with an ethnographic design. Data were collected through in-depth interviews, focus group discussion, observation, and nominal group process. The data
}

collected were analyzed using content analysis. The social, cultural, and economic conditions that strongly affected the pregnant women participation in integrated service post, because of the poverty. The social and cultural condition that affected belief in myths and food taboos which are highly contradictory to the medical rules. The economic conditions that affected is women have heavy domestic and productive workloads. Their physical and psychological burdens were excessively high that could endanger the health. The participation of pregnant women was not based on true awareness for maintaining their health but such participation was more based on their desires of getting one box of instant noodles. The participation model for the pregnant women was designed using participatory (nondirective) approach which was productive.

Keywords: Pregnant women, participation, integrated service post

\section{Pendahuluan}

Kesehatan ibu khususnya ibu hamil masih menjadi prioritas di Indonesia. Permasalahan utama kesehatan ibu hamil di Kabupaten Sampang adalah pemeriksaan antenatal (K1 dan K4 masing-masing adalah 86\% dan $70 \%$ ) dan persalinan oleh tenaga kesehatan $(73,58 \%){ }^{1}$ Salah satu kebijakan pembangunan bidang kesehatan yang dipergunakan untuk mengatasi permasalahan kesehatan di masyarakat adalah upaya pemberdayaan. ${ }^{2}$ Keberhasilan pemberdayaan dapat diketahui melalui berbagai indikator yang antara lain meliputi partisipasi masyarakat. ${ }^{3}$ Posyandu merupakan kegiatan pemberdayaan masyarakat dan merupakan ujung tombak pelayanan kesehatan ibu hamil. Perawatan kehamilan

Alamat Korespondensi: Shrimarti Rukmini Devi, Fakultas Kesehatan Masyarakat Universitas Airlangga, Jl. Mulyorejo Kampus C FKM Unair Surabaya 60115,Hp.081330704924,e-mail: s_r_devy@yahoo.co.id 
dan pemilihan penolong persalinan merupakan dua komponen penting yang perlu mendapat perhatian. Masyarakat tampaknya lebih mengacu pada tradisi dan nilai-nilai yang ada pada kedua komponen tersebut. Pemanfaatan pelayanan kesehatan di posyandu oleh ibu hamil untuk memeriksakan kehamilan secara kualitas belum terbukti secara maksimal. ${ }^{4}$ Faktor kemiskinan yang dominan di dalam masyarakat semakin memperkuat persepsi bahwa pemeriksaan kesehatan bukan merupakan partisipasi, tetapi kepatuhan masyarakat. ${ }^{5}$

Keberadaan imbalan mi instan di posyandu bertolak belakang dengan upaya pemberdayaan masyarakat yang bertujuan menumbuhkan kesadaran dan kemandirian masyarakat dalam pemanfaatan fasilitas pelayanan kesehatan. ${ }^{6}$ Alasan pernyataan tersebut adalah bahwa masyarakat umumnya masih belum menyadari bahwa rutinitas pemeliharaan kesehatan ibu pada masa hamil mempunyai andil yang besar pada kualitas kesehatan ibu dan bayi sehingga pada tahap awal masyarakat masih membutuhkan kegiatan pemasaran sosial dan pendampingan dari pihak luar, tanpa mengecilkan peran masyarakat pada proses perencanaan, pelaksanaan, monitoring, dan evaluasi kegiatan. ${ }^{7-11}$ Berdasarkan tujuh tipologi partisipasi, yang sesuai dengan karakteristik masyarakat di lokasi penelitian adalah tipe partisipasi pasif/manipulatif. ${ }^{4}$ Deskripsi tipe tersebut menyatakan bahwa masyarakat diberitahu tentang kondisi yang sedang atau telah terjadi, pengumuman dilakukan sepihak oleh pelaksana proyek tanpa memperhatikan tanggapan masyarakat. Pertukaran informasi terbatas pada kalangan profesional di luar kelompok sasaran. Penelitian ini mempunyai tujuan untuk mengidentifikasi kondisi sosial, budaya, dan ekonomi yang memengaruhi partisipasi ibu hamil ke posyandu.

\section{Metode}

Penelitian ini menggunakan metode kualitatif dengan rancangan etnografi dan mempunyai tiga subjek primer, yaitu ibu hamil, bidan desa, dan kader posyandu, sedangkan subjek sekunder adalah toma, toga, dan tenaga kesehatan.

Teknik yang digunakan untuk pengumpulan data adalah wawancara mendalam (17 ibu hamil, 2 bidan desa, 2 tokoh masyarakat), focus group discussion (6 kader), observasi (pelaksanaan posyandu), nominal group process (14 tokoh masyarakat dan tenaga kesehatan). Pemilihan dilakukan di Desa Rapa Laok di Kecamatan Omben karena desa tersebut merupakan salah satu desa siaga di Kabupaten Sampang. Puskesmas Omben juga telah ditunjuk menjadi pelayanan obstetri neonatal dan emergensi dasar (PONED). Penelitian dilakukan pada bulan Januari - Desember 2008. Data yang diperoleh dari pendekatan kualitatif akan diolah dengan content analysis.

\section{Hasil}

Rutinitas pemeriksaan kehamilan merupakan salah satu indikator perawatan kehamilan. Berdasarkan data penelitian, pemanfaatan pelayanan kesehatan di posyandu oleh ibu hamil diperoleh beberapa fenomena. Berikut rincian data dapat dilihat pada Tabel 1 .

Perawatan kehamilan dan pemilihan penolong persalinan oleh ibu hamil merupakan dua hal yang penting untuk mengendalikan angka kematian ibu (AKI). Dukun masih berperan penting pada perawatan kehamilan dan penolong persalinan. Data penelitian tentang alasan masyarakat lebih memilih bersalin pada dukun diperoleh dengan menggunakan. Nominal group technique yang diikuti oleh tokoh masyarakat yang berjumlah 14 orang, terdiri dari 1 kepala desa, 5 kepala dusun, 1 bidan desa, 1 bagas, 1 kepala puskesmas, 2 staf puskesmas, 2 kader posyandu, 1 ketua penggerak pembinaan kesejahteraan keluarga (PKK). Hasil pada Tabel 2.

Berdasarkan data tersebut, dapat disimpulkan bahwa budaya malarat merupakan penyebab urutan pertama para ibu hamil lebih memilih melahirkan pada dukun.

\section{Kondisi Budaya}

Masyarakat Madura di daerah penelitian mayoritas meyakini kebenaran budaya. Masyarakat akan melakukan apa saja yang dapat dilakukan demi keselamatan ibu dan bayinya. Data mengenai budaya diperoleh dari hasil wawancara dengan ibu hamil, bidan desa, dan focus group discussion kader. Keterkaitan budaya dan pemanfaatan pelayanan kesehatan mengacu pada tiga unsur budaya dapat dilihat pada Tabel 3 .

\section{Kondisi Ekonomi}

Kondisi ekonomi yang memengaruhi pemanfaatan posyandu oleh ibu hamil dinilai dari analisis gender. Data diperoleh dari wawancara dengan 15 orang meliputi tokoh masyarakat, seperti kepala desa, sekretaris desa, pengurus PKK, dan penyedia kesehatan (kepala puskesmas, bidan koordinator, perawat). Dapat disimpulkan bahwa peran kaum wanita tidak hanya pada kegiatan reproduksi dan kegiatan domestik rumah tangga, tetapi juga kegiatan produksi yang seharusnya ditangani kaum laki-laki (Tabel 4).

Data tersebut didukung oleh data dari hasil wawancara dengan bidan desa, sebagai berikut.

"Kewajiban wanita lebih beragam, mengurus rumah dan mencari nafkah keluarga. Kaum pria lebih banyak bekerja di luar desa, dengan jadwal pulang yang tidak menentu dan hasil yg tidak menentu."(Bidan T)

Kewenangan wanita untuk reproduksi juga tidak sepenuhnya karena perbedaan nilai anak laki-laki dan anak perempuan di masyarakat berbeda. Seperti yang diungkapkan oleh bidan desa berikut ini.

"Nilai anak laki-laki lebih tinggi di masyarakat. Bila 
Tabel 1. Pemanfaatan Pelayanan Kesehatan di Posyandu oleh Ibu Hamil

\begin{tabular}{|c|c|}
\hline Data Temuan & Kuotasi \\
\hline $\begin{array}{l}\text { Para ibu hamil, telah melakukan pemeriksaan ke pus- } \\
\text { kesmas, posyandu bahkan ke praktik bidan swasta }\end{array}$ & $\begin{array}{l}\text { "Kalau untuk periksa kehamilan telah lumayan } \\
\text { mau datang ke posyandu, puskesmas dan rumah } \\
\text { bidan." (Bidan desa T) }\end{array}$ \\
\hline $\begin{array}{l}\text { Posyandu menjadi pilihan utama karena setiap bulan } \\
\text { ibu hamil yang periksa mendapat satu dus mi instan } \\
\text { dari lembaga internasional untuk membantu makan- } \\
\text { an ibu hamil }\end{array}$ & $\begin{array}{l}\text { "Sekarang pada tahu, datang sendiri periksa ka- } \\
\text { rena dapat mi instan } 1 \text { dus. Malah yang ndak } \\
\text { hamil datang minta mi." (Kader S) }\end{array}$ \\
\hline $\begin{array}{l}\text { Para ibu hamil belum paham bahwa pemeriksaan ke- } \\
\text { hamilan sangat penting untuk mencegah berbagai ma- } \\
\text { salah kesehatan. Sebagai bukti, ketika tidak ada mi di } \\
\text { posyandu mereka batal memeriksakan diri }\end{array}$ & $\begin{array}{l}\text { "Jauh-jauh mereka datang untuk periksa dan } \\
\text { mengharap dapat mi. Jika mi tidak ada mereka } \\
\text { tidak mau periksa.Jarang yang bertanya ke bidan } \\
\text { atau kader." (Kader } \mathrm{N})\end{array}$ \\
\hline $\begin{array}{l}\text { Para ibu hamil umumnya tidak tahu jenis pemeriksa- } \\
\text { an kehamilan yang dilakukan sehingga pengawasan } \\
\text { kualitas pelayanan oleh ibu hamil menjadi rendah }\end{array}$ & $\begin{array}{l}\text { ”...Nurut aja sama bu bidan, nggak tau apa aja } \\
\text { yang diperiksa, nurut aja." (Ibu hamil S) } \\
\text { “...Dikasih pil diterima tapi kadang tidak dima- } \\
\text { kan. Kalo disuntik senang, katanya di badan e- } \\
\text { nak." (Bidan } \mathrm{H} \text { ) }\end{array}$ \\
\hline $\begin{array}{l}\text { Para ibu hamil telah rajin datang periksa kehamilan } \\
\text { ke posyandu tapi tetap memanggil dukun untuk pijat, } \\
\text { melihat dan membenarkan letak bayi }\end{array}$ & $\begin{array}{l}\text { "Ibu hamil ke posyandu iya ke dukun iya. Mere- } \\
\text { ka percaya dukun pintar melihat dan membenar- } \\
\text { kan posisi bayi. Bidan tidak dapat." (Kader O) }\end{array}$ \\
\hline $\begin{array}{l}\text { Menurut pandangan masyarakat, bidan lebih pandai } \\
\text { melihat kesehatan ibu hamil dan melihat bayi masih } \\
\text { hidup atau telah mati }\end{array}$ & $\begin{array}{l}\text { Bidan pandai mengobati ibu dan tahu bayinya } \\
\text { hidup atau tidak." (Kader A) }\end{array}$ \\
\hline $\begin{array}{l}\text { Ada budaya "malu" beberapa ibu hamil menjadi ala- } \\
\text { san tidak periksa. Mereka adalah ibu muda yang ha- } \\
\text { mil pertama dan ibu yang terlalu sering hamil }\end{array}$ & $\begin{array}{l}\text { "Ada yang malu karena baru pertama hamil" } \\
\text { (Kader } \mathrm{N}) \\
\text { "Anaknya telah banyak, makanya malu" } \\
\text { (Bidan T) }\end{array}$ \\
\hline
\end{tabular}

belum punya anak laki, suami terus menuntut istri hamil sampai melahirkan anak laki-laki. Tidak peduli kondisi istri (kesehatan dan usia)."(Bidan T)

Kondisi tersebut yang berkontribusi memperburuk kondisi kesehatan para ibu. Ironisnya, eksistensi kaum wanita pada kegiatan manajemen masyarakat tetap belum maksimal sehingga tidak ada keberanian dari para ibu untuk menyampaikan haknya bereproduksi.

Menurut hasil penelitian tentang pendapatan per bulan, dari $17 \mathrm{ibu}$ hamil yang menjadi responden, 15 orang berpenghasilan kategori rendah. Acuan penghasilan adalah upah minimum regional (UMR) Kabupaten Sampang sejumlah Rp700.000. Dari hasil penelitian juga diperoleh data yang mendukung bahwa mayoritas masyarakat di lokasi penelitian adalah masyarakat miskin sehingga kesehatan bukan prioritas bagi mereka. Bahkan dalam kondisi hamil, seorang ibu tetap harus bekerja dan setelah melahirkan harus bekerja mengerjakan tugas rumah tangga. Setelah 40 hari, ibu bekerja di luar rumah.

"Hamil muda sampe tua, tetap kerja mencari uang, setelah lahir tetap kerja rumah tangga, setelah 40 hari mulai kerja keluar rumah mencari uang."(Kader S)

Kemiskinan yang menyebabkan para ibu hamil seringkali lebih memilih bekerja daripada memeriksakan kehamilannya.

\section{Partisipasi Ibu Hamil di Posyandu}

Fenomena partisipasi para ibu hamil untuk datang ke posyandu sesuai kategori partisipasi masyarakat yang dikemukakan oleh Slamet, dinilai berdasarkan input yang disumbangkan dan keikutsertaan dalam memanfaatkan hasil pembangunan, dapat dilihat pada Tabel 5 .

Berdasarkan hasil observasi, kondisi partisipasi masyarakat pada pelayanan kesehatan yang ada, dikategorikan pada ragam partisipasi nomor empat karena tidak semua para ibu hamil sebagai anggota masyarakat dapat menikmati hasil pembangunan. Bahkan untuk memeriksakan diri, masyarakat meminta imbalan. Fenomena yang ada, ibu hamil yang datang periksa mendapat imbalan mi instan satu dus.

\section{Pembahasan}

Perawatan kehamilan dan pemilihan penolong persalinan merupakan dua komponen penting yang perlu mendapat perhatian. Masyarakat lebih mengacu pada tradisi dan nilai-nilai yang ada pada budaya kedua hal tersebut. Pemanfaatan pelayanan kesehatan di posyandu oleh 
Tabel 2. Alasan Masyarakat Lebih Memilih Melahirkan pada Dukun

\begin{tabular}{lll}
\hline \multicolumn{1}{c}{ Masalah } & \multicolumn{1}{c}{ Hasil } & \multicolumn{1}{c}{ Solusi } \\
\hline $\begin{array}{l}\text { Mengapa ibu hamil di desa ini lebih me- } \\
\text { lebih memilih melahirkan ke dukun? }\end{array}$ & $\begin{array}{l}\text { Dari 14 jawaban dirangkum menjadi li- } \\
\text { ma berdasarkan prioritas, antara lain } \\
\text { budaya malarat, biaya persalinan bidan } \\
\text { yang mahal, keluarga ikut campur mem- } \\
\text { beri keputusan, takut operasi, dan ber- } \\
\text { obat ke puskesmas, pengetahuan kese- } \\
\text { hatan ibu hamil yang rendah. }\end{array}$ & $\begin{array}{l}\text { Solusi dari lima masalah tersebut meli- } \\
\text { puti musyawarah aparat desa, puskes- } \\
\text { mas, dan tokoh masyarakat, menyepa- } \\
\text { kati aturan dukun boleh bekerja sebagai } \\
\text { perawat bayi (alih fungsi dukun). }\end{array}$ \\
& & $\begin{array}{l}\text { Health education berbasis agama pada } \\
\text { ibu hamil dalam kelompok dasawisma } \\
\text { dengan melibatkan tenaga kesehatan, }\end{array}$ \\
& & toma, toga, dan kader. \\
& & Kemitraan dengan dukun dengan mem- \\
& beri uang 50 ribu untuk mendampingi \\
persalinan bidan. & Biaya yang mahal, dapat diatasi dengan \\
& & Jamkesmas dan periksa gratis, kegiatan \\
produktif masyarakat, misalnya pembu- \\
atan pupuk, menanam sayur organik.
\end{tabular}

Tabel 3. Budaya Masyarakat yang Memengaruhi Pemanfaatan Posyandu oleh Ibu Hamil

\begin{tabular}{lll}
\hline Unsur Budaya & \multicolumn{1}{c}{ Mitos yang Diyakini Masyarakat } & \multicolumn{1}{c}{ Alasan } \\
\hline Unsur ide & $\begin{array}{l}\text { Pandangan hidup bahwa ibu yang meninggal karena } \\
\text { melahirkan masuk surga } \\
\text { Anak bayi yang meninggal akan menjemput ibunya } \\
\text { di surga }\end{array}$ & $\begin{array}{l}\text { Dianggap jihad, jadi tidak masalah, dan ti- } \\
\text { dak perlu dipermasalahkan } \\
\text { Bayi masih suci jadi langsung masuk surga. } \\
\text { Jadi semakin banyak anak yang meninggal } \\
\text { Snsur aktivitas }\end{array}$ \\
& $\begin{array}{l}\text { Tidak boleh makan nanas, mangga kuini dan daun } \\
\text { ketela pohon } \\
\text { Tidak boleh minum softdrink } \\
\text { Tidak boleh makan nasi dan panganan terlalu banyak }\end{array}$ & $\begin{array}{l}\text { Karena panas dan menyebabkan keguguran } \\
\text { khawatir keguguran, bayi dapat besar dan }\end{array}$ \\
& $\begin{array}{l}\text { Tidak boleh makan ikan laut } \\
\text { Ibu hamil harus membawa gunting atau jarum, saat } \\
\text { keluar rumah di atas waktu maghrib }\end{array}$ & Menolak kekuatan gaib yang jahat \\
\hline
\end{tabular}

ibu hamil untuk memeriksakan kehamilan secara kualitas belum maksimal. ${ }^{4}$ Faktor kemiskinan yang dominan di masyarakat, semakin memperkuat persepsi bahwa pemeriksaan kesehatan bukan partisipasi tetapi kepatuhan masyarakat. ${ }^{5}$ Keberadaan imbalan mi instan di posyandu bertolak belakang dengan upaya pemberdayaan masyarakat yang bertujuan menumbuhkan kesadaran dan kemandirian masyarakat dalam pemanfaatan fasilitas pelayanan kesehatan. ${ }^{6}$ Masyarakat umumnya masih belum menyadari bahwa rutinitas pemeliharaan kesehatan ibu pada masa hamil mempunyai andil besar pada kualitas kesehatan ibu dan bayi sehingga pada tahap awal masyarakat masih membutuhkan kegiatan pemasaran sosial dan pendampingan dari pihak luar, tanpa mengecilkan peran masyarakat pada proses perencanaan, pelaksanaan, monitoring dan evaluasi kegiatan. ${ }^{7-11}$

Berdasarkan tujuh tipologi partisipasi, yang sesuai dengan karakteristik masyarakat di lokasi penelitian, adalah tipe partisipasi pasif/manipulatif. ${ }^{4}$ Deskripsi tipe tersebut menyatakan bahwa masyarakat diberitahu tentang kondisi yang sedang atau telah terjadi, peng- umuman dilakukan sepihak oleh pelaksana proyek tanpa memperhatikan tanggapan masyarakat. Informasi yang dipertukarkan terbatas pada kalangan profesional di luar kelompok sasaran. Pelayanan kesehatan di masyarakat dapat berhasil maksimal, apabila dapat mengakomodasi kearifan lokal. ${ }^{12}$ Kondisi sosial dan budaya yang berpengaruh pada partisipasi ibu hamil di posyandu dapat diatasi dengan perubahan perilaku kesehatan ibu hamil melalui kegiatan pendidikan kesehatan dan siraman rohani secara rutin dan berkesinambungan, sedangkan kondisi ekonomi yang berpengaruh pada partisipasi ibu hamil di posyandu dapat diatasi dengan kegiatan produktif.

Berdasarkan data penelitian dan masukan masyarakat, peneliti memodifikasi kegiatan yang tepat guna bagi ibu hamil dan masyarakat di Desa Rapa Laok. Penyuluhan kelompok terhadap sasaran ibu hamil dilakukan oleh bidan desa dan kader dengan frekuensi sekali sebulan. Peningkatan frekuensi pendidikan kesehatan yang berkesinambungan, mendukung perubahan sikap dan perilaku ibu hamil. Latihan keterampilan 
Tabel 4. Kondisi Sosial Ekonomi yang Berpengaruh pada Pemanfaatan Posyandu oleh Ibu Hamil Berdasarkan Analisis Gender

\begin{tabular}{|c|c|c|c|}
\hline Kegiatan & Kategori & Perempuan Dewasa & Laki-laki Dewasa \\
\hline \multirow[t]{9}{*}{ Produksi } & Membersihkan lahan & 12 & 15 \\
\hline & Menanam benih & 13 & 15 \\
\hline & Menyiram tanaman & 12 & 15 \\
\hline & Menyemprot tanaman & 4 & 15 \\
\hline & Memupuk tanaman & 10 & 15 \\
\hline & Memanen & 14 & 15 \\
\hline & Menjemur & 13 & 15 \\
\hline & Mengepak dalam karung & 8 & 15 \\
\hline & Menjual hasil & 7 & 15 \\
\hline \multirow[t]{4}{*}{ Reproduksi } & Mengatur kehamilan & 13 & 7 \\
\hline & Memeriksakan kehamilan & 15 & 0 \\
\hline & Merencanakan kelahiran & 14 & 11 \\
\hline & $\begin{array}{l}\text { Mengatur pemberian air susu ibu } \\
\text { dan makanan bayi }\end{array}$ & 15 & 0 \\
\hline Jasa masyarakat dan jasa & Mengumpulkan bahan bakar & 9 & 10 \\
\hline \multirow[t]{13}{*}{ rumah tangga utama } & Mengambil air bersih & 15 & 11 \\
\hline & Memandikan anak & 15 & 3 \\
\hline & Menyuapi anak & 15 & 2 \\
\hline & Menyiapkan makanan & 15 & 0 \\
\hline & Merawat pekarangan & 12 & 10 \\
\hline & Mencuci baju & 15 & 0 \\
\hline & Membersihkan rumah & 15 & 4 \\
\hline & Memberi makan ternak & 10 & 14 \\
\hline & Memandikan ternak & 2 & 15 \\
\hline & Menjual hasil ternak & 3 & 15 \\
\hline & Menjual ternak & 2 & 15 \\
\hline & Belanja makanan & 15 & 1 \\
\hline & $\begin{array}{l}\text { Belanja kebutuhan keluarga } \\
\text { selain makanan }\end{array}$ & 15 & 9 \\
\hline \multirow[t]{2}{*}{ Manajemen masyarakat } & Menyiapkan kegiatan desa & 9 & 15 \\
\hline & Ikut kegiatan rembug desa & 6 & 15 \\
\hline
\end{tabular}

Tabel 5. Kategori Partisipasi Masyarakat

\begin{tabular}{lllllll}
\hline & \multicolumn{5}{c}{ Ragam Partisipasi } \\
\cline { 2 - 6 } Partisipasi yang ditunjukkan & $\mathbf{1}$ & $\mathbf{2}$ & 3 & 4 & $\mathbf{5}$ \\
\hline Memberikan input & + & + & + & - & + \\
Menerima imbalan atas input yang diberikan & + & - & + & - & - \\
Menikmati manfaat hasil & + & + & - & + & - \\
\hline
\end{tabular}

\section{Keterangan:}

$1=$ partisipasi penuh

2 = partisipasi tanpa menerima imbalan atas input yang diberikan

3 = partisipasi tanpa menikmati manfaat hasil

$4=$ partisipasi tanpa memberi input dan tidak menerima imbalan atas hal tersebut

5 = partisipasi tanpa menerima imbalan atas input dan tidak menikmati manfaat hasil

kegiatan produktif seperti pembuatan pupuk organik dengan sasaran ibu hamil dan masyarakat, dilakukan olah ahli pertanian, staf desa, dan tokoh masyarakat dengan frekuensi sebulan sekali. Kegiatan produktif inovatif yang sesuai keterampilan masyarakat dan kondisi sumber daya alam setempat dapat dijadikan mata pencaharian. Kegiatan siraman rohani terkait kesehatan ibu hamil dilakukan dengan sasaran ibu hamil, keluarga, dan masyarakat. Pelaku adalah tokoh agama dan tokoh masyarakat dengan frekuensi sebulan sekali. Kegiatan pendidikan kesehatan dikemas dalam siraman rohani oleh para ulama sebagai tokoh panutan masyarakat Madura. Masalah kesehatan tidak selalu disebabkan oleh faktor medis, solusi yang tepat memerlukan pemahaman akar masalah, bahkan memungkinkan penanganan dengan kerjasama lintas institusi.

\section{Kesimpulan}

Kualitas partisipasi ibu hamil ke posyandu belum maksimal ada kerancuan antara partisipasi dan kepatuhan. Dukun masih berperan penting pada perawatan kehamilan dan penolong persalinan, budaya malarat merupakan penyebab urutan pertama para ibu hamil lebih memilih melahirkan pada dukun. Masyarakat di daerah penelitian yang mayoritas meyakini kebenaran budaya akan melakukan apa saja yang dapat dilakukan demi keselamatan ibu dan bayinya. Peran kaum wanita tidak hanya pada kegiatan reproduksi dan kegiatan domestik rumah tangga, tapi juga kegiatan produksi yang seharusnya ditangani kaum laki-laki. Kondisi partisipasi masyarakat pada pelayanan kesehatan yang ada dikategorikan pada ragam partisipasi tanpa memberi input dan tidak menerima imbalan. 


\section{Saran}

Pendekatan partisipatif yang produktif, merupakan cara tepat untuk partisipasi ibu hamil ke posyandu. Peningkatan frekuensi pertemuan nonformal rutin antara bidan desa, kader dengan ibu hamil secara berkelompok dengan mengemas kegiatan dengan muatan kesehatan ibu hamil, siraman rohani dan kegiatan produktif yang mampu dilakukan oleh para ibu hamil, yang pada gilirannya dapat meningkatkan pendapatan bagi ibu hamil dan keluarga.

\section{Daftar Pustaka}

1. Dinas Kesehatan Kabupaten Sampang. Profil kesehatan. Kabupaten Sampang: Dinas Kesehatan; 2009.

2. Kementerian Kesehatan Republik Indonesia. Sistem kesehatan nasional. Jakarta: Kementerian Kesehatan Republik Indonesia; 2004.

3. Hikmat H. Strategi pemberdayaan masyarakat. Bandung: Humaniora Utama Press; 2004

4. Mardikanto T. Model-model pemberdayaan masyarakat. Surakarta: Universitas Negeri Sebelas Maret Press; 2010.

5. Sciortino R. Menuju kesehatan madani. Yogyakarta: Pustaka Pelajar; 1999.
6. Pemerintah Republik Indonesia dan UNICEF. Paket komunikasi informasi edukasi: untuk pemberdayaan masyarakat di bidang Kesehatan ibu dan anak. Jakarta: Kementerian Kesehatan Republik Indonesia; 2000.

7. Istiarti T, Johanna EP. Pengetahuan, sikap, dan praktik ibu hamil terhadap pelayanan antenatal dan hubungannya dengan berat badan bayi lahir rendah. Sains Kesehatan. 1999; 12 (9): 59-67.

8. Senewe, Felly P, Ning S. Faktor-faktor yang berhubungan dengan komplikasi persalinan tiga tahun terakhir di Indonesia. Buletin Penelitian Kesehatan. 2004; 32 (2): 83-91.

9. Roosihermiatie B, Suhardono,Wahyu DA, Andryansyah A. Pandangan tentang kehamilan-persalinan dan pengaruhnya terhadap persalinan oleh tenaga kesehatan/bidan di dua Puskesmas Kabupaten Jember. Buletin Penelitian Sistem Kesehatan. 2004; 7 (2): 118-28.

10. Syafrie R, Djaswadi D, Jauhar I. Hubungan kausalitas pelayanan antenatal terhadap kejadian BBLR di Kabupaten Purworejo. Sains Kesehatan. 2004 ; 17 (2): 191 - 203.

11. Arifin, Andryansyah. Persepsi ibu hamil tentang antenatal care dan persalinan. Buletin Penelitian Sistem Kesehatan. 2005; 8 (2): 84-9.

12. Kalangie, Nico S. Kebudayaan dan kesehatan: pengembangan pelayanan kesehatan primer melalui pendekatan sosiobudaya. Jakarta: Megapoin; 1994. 